Discourse and Communication for Sustainable Education, vol. 12, no. 1, pp. 140-150, 2021

\title{
Sustainable Career Guidance During the Pandemic: Building Pathways into a 'New Normal'
}

\author{
Sandra Šapale, Dzintra Iliško and Jel̦ena Badjanova \\ Daugavpils University, Daugavpils, Latvia
}

\begin{abstract}
The COVID-19 pandemic has influenced regular patters of career guidance. Globally everything has stopped: projects were postponed, and workplaces were closed but this situation has pushed career counselors to search for new opportunities about how career guidance could be carried out. The pandemic has intensified existing challenges in society, adding complexity for the processes of a transition of educational systems towards digitalization and have intensified the need for remote career guidance. Young people become particularly vulnerable to the digital divide. Career development support has been at risk with the emergence of an unpredictable future. However, career guidance during the pandemic can serve as a tool for understanding the situation in depth and searching for new opportunities that exist, by helping individuals to overcome anxiety. While practicing physical distancing, career counselors have kept active professional networks in assisting their clients with their needs. The operation of career guidance has been transferred mainly to the online format and has required the counselors to develop new skills and competencies. The methodology employed in this study included interviews with individual career counselors about the main challenges and solutions discovered during the lockdown. Career counselors were questioned also about how they shaped a more sustainable and flexible online career guidance system. They revealed details about their struggles and hopes encountered in the situation of crises. The authors point to critical areas for improvement that career counselor can provide to their clients during the lockdown.
\end{abstract}

Key words: career guidance, sustainability competences, pandemic, online career guidance system, resilience

\section{Introduction}

The pandemic has influenced processes worldwide and brought up many negative impacts into daily life by changing the work routine in line with closure of schools and businesses. The pandemic was reshaping the perception of individuals about work resulting in micro and macro shifts in the world of work. The pandemic has resulted in dramatic changes in employment that caused employment disparities. As Millar et al. (2018) asserted, this pandemic has brought about uncertainty, complexity and ambiguity. In 
this situation, career guidance becomes more complicated in how to meet individual's needs and how to improve their career adaptability. The pandemic therefore has brought changes in the organization of work; in particular, this has brought up the possibility of study and work from the home office.

The transition to 'A New Normal' has caused anxiety and stress among a majority of learners. Therefore, the career counselors have been looking for new opportunities in order to address current challenges, thus providing their clients with the opportunities for evaluating their skills in order to build a more sustainable career path. They undertook responsibility to reach the psychological issues of learners, providing them support while exploring their interests and values, by being aware of their survival and social connection needs. They have also provided mental health intervention for their students. As Akkermans, Richardson and Kraimerc (2020) assert, certain resources, such as career competencies and resilience, could make crises more manageable for many participants. The pandemic and the digital revolution have shifted and transformed the nature of work. Therefore, there is a need for new models of career guidance.

\section{The Challenges of the Career Counselors in the "New Normal"}

The pandemic has resulted in disruption of national economies and educational systems worldwide. Many educational establishments have made their transition to online teaching. The New Normal has influenced the way that carrier advisors continued to reach their students. One of the challenges during the pandemic that many schools have encountered was how to ensure career guidance that meets the needs of digital generation (Pittman, Severino, DeCarlo-Tecce, \& Kiosoglous, 2021). Contemporary young people are already connected globally via social media and other channels. They are very skillful in using digital tools that allow them to receive immediate feedback from these devices on a daily basis. Therefore, career advisors also need to acquire digital literacy for providing support to their students in order to reach them via digital devices alongside with the traditional means of interaction. Another challenge raised was how to ensure inclusive quality career guidance by ensuring accessibility for all students. The pandemic has revealed a growing digital divide.

The intervention of a career counselor during the pandemic needs to be centered around the basic physiological, social and self-realization needs of students that were eroded during the pandemic (Duffy et al., 2016). Another issue to deal with is work and leisure time balance that was also disrupted during the pandemic. There are a number of benefits from work and studies from home, saving time and finance outlay that individuals needed otherwise to spend on travel. However, working from home for many professionals resulted in blurred boundaries between work and leisure time. Career counselors needed to find a balance between work time and leisure activities and needed to provide quality guidance to their students (Cho, 2020). Hite and McDonald (2020) point to a number of challenges that career counselors are facing, including how to develop resilience in facing the post pandemic situation, advancing technological skills, overcoming the blurring work-leisure divide, the intensification of work, unpredictability and unknowing, by identifying risks and protective factors in one's life and identifying the contextual factors that influence one's career resilience. Hobfoll's (1989) theory of Conservation of Resources (COR) could be a helpful reference in helping young people to sustain their resources, building their resilience in the context of uncertainty. Hite 
and McDonald (2020) suggest practicing self-care in seeking a support among friends, colleagues and online community in order to meet social and emotion needs of individuals.

\section{Conceptualizing Sustainable Career Discourse}

The sustainable career path has been conceptualized in relation to learning agility, employability, and in relation to a work-leisure balance. There is a lack of empirically grounded theoretical frameworks for defining a sustainable career guidance process. De Vos, Beatrice, Van der Heijdenb and Akkermanse (2018) suggest defining a sustainable career in a dynamic perspective as interconnected and influenced by a number of contextual factors. This requires adapting a systemic approach in order to understand the interconnectedness of all factors, and openness to a dynamic learning. The authors point to three indicators of sustainable careers such as health, happiness, and productivity. All concepts require a holistic framework. By describing sustainability of a career choice, Stuer et al. (2019) talk about workability - one's ability to work in a healthy and productive way while balancing person's resources: health, functional abilities, education, values and attitudes. To achieve high levels of workability, one needs to become mindful of a meaningful existence by expanding one's resources and enhancing future perspectives of workability (Kira \& Eijnatten, 2008; Kira, van Eijnatten, \& Balkin, 2010). Airila et al. (2014) add a resource perspective to the existing body of research by emphasizing the need to focus on individuals' resources and a unique motivational potential that one already has but that needs to be rediscovered. Stuer et al. (2019) in their conceptual model have added a future-orientedness aspect of one's job that needs to be highlighted and reemphasized by the career counselors. Haenggli and Hirschi (2020) suggest focusing on career adaptability resources that can ensure the success of one's career. On the base of already suggested models, the authors propose the conceptual model of sustainable career guidance for the adolescents.

\section{Figure 1}

\section{Conceptual Model of a Sustainable Career Guidance}

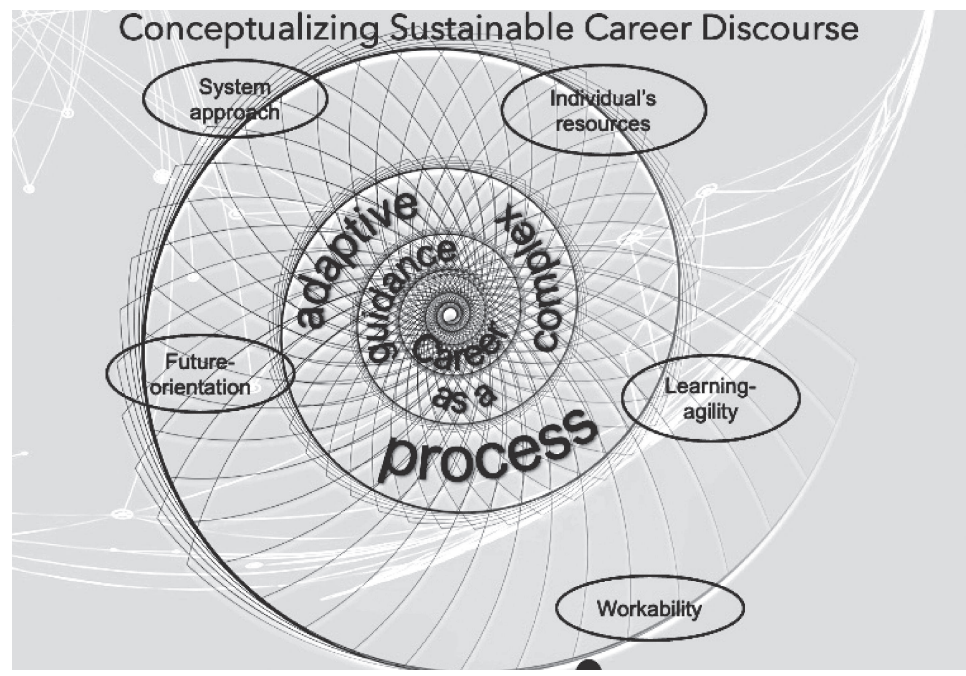


Heslin, Keating, and Ashford (2020) refer to a 'meta-competency in the quest for career sustainability' (p. 11) that includes one's willingness to make changes, to learn and to adapt with a smoother transition to a post - COVID-19 turbulent situation. Chudzikowski, Gustafsson and Tams (2020) refer to a need of a sustainability culture that can support the growth of an individual participant. Lawrence, Hall, and Arthur (2017) suggest the use of an interdisciplinary approach to better explain sustainability in a career choice, since careers are interdependent with peoples' lives and can be seen from a systems perspective. The study develops a perspective based on the complex adaptive system theory that involves nonlinear thinking and outcomes that depend on interaction of participants composing those systems (Heasly et al., 2020; Salite et al., 2020). Career decision process is a highly complex process. Therefore, complexity of thinking should be embedded in career decision-making processes leading to adopting a flexible and adaptive approach towards building one's career (Drodge, 2002). Hirshi (2012) conceptualizes adaptability as a meta competency that enables the individual to adapt other competencies, including an integrative component. Adaptability has involved individuals in adapting to changing career circumstances and an ability to handle stresses in a new career situation. It also refers to needing such individual's features as openness, internal focus of control and self-efficiency. The proposed model is influenced by Chaos theory that see the process of building one's career as "a complex interchangeability and connectedness of diverse elements (Pryor, 2010), involving the elements of complexity, change, construction and uncertainty. According to the theory, career development is nonlinear, therefore the students need to be encouraged to develop optimism about their future, open mindedness and creativity.

The emergence of complexity science requires one to reexamine the existing models of career guidance by relating it to such metaphorical concepts as bifurcation, nonlinearity, and self-organization. By acting within this new framework, the career adviser can assist the student in coping with uncertainty and reducing the experience of anxiety much better. Complexity theory allows one to understand that safety, a linear and predictable future that is embedded in one's traditional understanding and epistemology, is a myth. The pandemic unleashed the potential of creativity and expanded the range of career development pathways. As Drodge (2002) asserts, complexity science points to "an inevitability of change" and "the beauty of unpredictability" (p. 55) and requires "theoretical heterogeneity" (p. 61) in order to take into account all career building experiences. Career building should be seen as a dynamic and nonlinear system that needs to be seen in the context of one' career development patterns, person's work life, socio-economic constraints, habits of mind, internal and external factors and the dynamics of a particular person (Bloch, 2003). Different situations of crises, like a pandemic, bring new shape and forms to the development of one's career. Obolensky (2014) refers to adaptability as one of the features of an open adaptive system that describes one's career building processes. It involves awareness of the local context and one's capability to change internally. Each individual needs to have skills to adapt to the internal and external forces in the situation of instability and disequilibrium in order to reach high levels of self-organized systems. 


\section{Research Methodology and Participants}

For the purpose of the study the authors have carried out focus group interviews with the career counselors by making an inquiry about challenges they are dealing within the New Normal, including transformations that they have introduced in the organization process of a career guidance. This inquiry both asks what are the main tools that they use during the lockdown and how do they shape a more flexible and sustainable online career guidance system. To ensure the triangulation of data, the authors carried out ten sixty-minutes long semi-structured interviews with the career counselors from Latgale region in the Zoom platform. Ten career advisers represented different age groups, genders and different experiences of work as career counsellors. The interviews were carried out with the aim of a better understanding about the impact of the Covid-19 pandemic, and in particular, decisions and actions taken by the career advisors regarding how to provide quality career guidance. The interviews allowed to disclose how participants are engaging in sense making and learning processes during this unprecedented time.

\section{Table 1}

\section{Research Participants}

\begin{tabular}{|c|c|c|c|}
\hline $\begin{array}{l}\text { Research } \\
\text { participants }\end{array}$ & Work experience & Workplace & $\begin{array}{l}\text { Adaptability to new } \\
\text { online career guidance }\end{array}$ \\
\hline Ann & $\begin{array}{l}\text { Career counsellor since } \\
1998,52 \text { years old }\end{array}$ & $\begin{array}{l}\text { Works at the school } \\
\text { library }\end{array}$ & $\begin{array}{l}\text { Concerned about emotional } \\
\text { well-being and fatigue of clients }\end{array}$ \\
\hline Biruta & $\begin{array}{l}\text { Career counsellor since } \\
2009,50 \text { years old }\end{array}$ & $\begin{array}{l}\text { Works in the kinder- } \\
\text { garten }\end{array}$ & $\begin{array}{l}\text { Struggling to find work- } \\
\text { leisure balance }\end{array}$ \\
\hline Cecilia & $\begin{array}{l}\text { Career counsellor since } \\
2018,28 \text { years old }\end{array}$ & $\begin{array}{l}\text { Works in the technical } \\
\text { school }\end{array}$ & $\begin{array}{l}\text { Open to new Normal and a new } \\
\text { learning situation }\end{array}$ \\
\hline Daina & $\begin{array}{l}\text { Career counsellor since } \\
2010,55 \text { years old }\end{array}$ & $\begin{array}{l}\text { Works in the school } \\
\text { for children with } \\
\text { special needs }\end{array}$ & $\begin{array}{l}\text { Struggling to adjust to a new } \\
\text { situation }\end{array}$ \\
\hline Elsa & $\begin{array}{l}\text { Career counsellor since } \\
2019,46 \text { years old }\end{array}$ & $\begin{array}{l}\text { Works in the gymna- } \\
\text { sium }\end{array}$ & $\begin{array}{l}\text { Struggling to build communi- } \\
\text { cation via digital tools }\end{array}$ \\
\hline Fjodor & $\begin{array}{l}\text { Career counsellor since } \\
2018,40 \text { years old }\end{array}$ & $\begin{array}{l}\text { Works in a technical } \\
\text { school }\end{array}$ & $\begin{array}{l}\text { Open to a new learning experi- } \\
\text { ence and forms of work }\end{array}$ \\
\hline Alina & $\begin{array}{l}\text { Career counsellor since } \\
2019,27 \text { years old }\end{array}$ & $\begin{array}{l}\text { Works in the secon- } \\
\text { dary school setting }\end{array}$ & Very open and flexible \\
\hline Juris & $\begin{array}{l}\text { Career counsellor since } \\
2019,26 \text { years old }\end{array}$ & $\begin{array}{l}\text { Works in the secon } \\
\text { dary school }\end{array}$ & Very open and flexible \\
\hline Maigurs & $\begin{array}{l}\text { Career counsellor since } \\
2019,28 \text { years old }\end{array}$ & $\begin{array}{l}\text { Works in the basic } \\
\text { school }\end{array}$ & $\begin{array}{l}\text { Open to integrate ICT tools and } \\
\text { make good use of digital } \\
\text { platforms }\end{array}$ \\
\hline Svetlana & $\begin{array}{l}\text { Career counsellor since } \\
2019,28 \text { years old }\end{array}$ & $\begin{array}{l}\text { Works in the basic } \\
\text { school }\end{array}$ & $\begin{array}{l}\text { Very flexible in adjusting to a } \\
\text { new format of 'A New Normal' }\end{array}$ \\
\hline
\end{tabular}

Among the limitations of the study are subjectivity of judgement of three researchers in the process of coding and analysing the interview data. The conceptual model is not intended to be all encompassing, all-size-fit model but was designed to complement current practices of career guidance. Finally, the data collection was limited to the participants of Latgale region. 


\section{Research Findings}

The authors carried out a focus group interview with ten career counselors in order to inquire about their experience of organizing career guidance during the lock-down. All of them pointed to huge changes and transitions in the organization of career guidance process. They all did talk about the pandemic as time that made people think more about themselves and their careers, values and the way they spent their lives. They all pointed out that career guidance as a tool that helped adolescents and youth to manage their study-leisure time balance and to cope with the anxiety and unknowing. They pointed to the main challenges: how to organize career guidance in a new format; how to provide emotional support to youth; how to minimize social isolation; and how to respond to the emotional and social needs of youth. The authors have derived the main categories from the individual interviews with the career counselors, namely, challenges of organizing career counseling process, new learning experience; they referred to the aspects of career counselor's well-being, and a sustainability of a career guidance process. The respondents highlighted the practice of individual solutions in providing integrated learning pathways towards a more sustainable recovery.

The first interview question was how the pandemic has affected the life and wellbeing of a career counsellor.

Career counsellors expressed feelings of care about their students, worries about their work routine, doubts whether everything was done correctly and smoothly, discussed about fatigue, and depression among the interviewed participants during the pandemic.

The respondents reported that the pandemic provided numerous opportunities for the career counsellors, like attending online seminars that gave them inspiration for work in a new online format: "Universities and colleges offered numerous webinars for the career counsellors that helped to survive during the pandemic and gave an inspiration for work in a new format" (Ann, 52 years old). "Online seminars have made an impact on my work as a career counsellor by providing guidelines how to work with the groups and individuals" (Biruta, 50 years). Career counsellors described pandemic conditions as an opportunity for learning: "I have learned new things: particularly, how to apply the ICT's for the career consoling." At the same time, they reported about the feeling of fatigue and depression during the pandemic: "Both students and educators experience passivity, fatigue. This is not easy to face a constant change" (Cecilia, 28 years).

Among the most urgent tasks during the pandemic that they have mentioned was how to address emotional and social needs of youth. The pandemic has changed the way we live and interact with each other, and how we work. As one of the interviewed career experts commented: "Pandemic is time when adolescents' psychological needs for a social interaction is coming into a forefront. Pandemic has challenged us with real complex social and emotional challenges. Therefore, career guidance is vitally important in helping people to find meaning in their lives." There is an increasing demand for psychosocial support among pupils of all ages. One of the career experts reported: "This is essential to identify stressors and the concerns of youth and to provide them with necessary support." They did complain about a lack of communication among the stakeholders. For example, Daina has reported: "There is a lack of conversations with the students and their parents. There is a constant fatigue among the students" (Daina, 55 years). "They did talk about ignorance, a lack of information about admission exams in universities and depression among the career counsellors caused by inability to respond young people's needs" (Elsa, 46 years old). 
Career counselors did talk about the challenge of how to make a transfer to a new online format. The authors have made an inquiry about the main modes of delivery of career guidance. They all adjusted to the need to provide career services via different formats (skype, Zoom, telephone, e-mail). Remote support is more flexible, learnercentered in approaching a contemporary young person. The lockdown triggered the use of web-based interactive tools. The transfer to online career guidance has highlighted a number of issues: the availability of ICT infrastructure, the attitude of career experts towards online career guidance, a lack of experience of work in a new situation. The resilience and commitment of career experts played a major role in responding to crises. They had to learn and improve their skills of how to use digital tools and how to adapt their programs to a digital format. All experts reported that their organization was very flexible in making a transition to a New Normal. One of them reported: "I adapted quite quickly. I developed a range of online materials and made them available for pupils. I was available for my students in helping them to deal with the anxiety, worries about the future by providing them the required information." Pupils have easily adapted to a new situation and responded to the use of technologies. A shift to online career support services has pushed career counselors to upgrade their technological skills and they have undergone online training. They reported details of the use of various means of communication such as emails, what's up, video calls, Zoom, google meet platforms.

The next question was related to the forms of work, the methods that they used during the pandemic. Career counsellors have passionately shared their experience about the methods that were used before the pandemic: "I carried out group and individual counselling in a new online format" (Anna, 52). "I used such methods, such as games and discussions. I prefer to work in face-to-face format. In this way I can address students' needs personally" (Cecilia, 28). Another respondent reported about the organization of "a variety of informative events" (Daina, 55). "I did organize a group work, I played different games, and used interactive communication tools” (Elsa, 46). All interviewed career counsellors responded about the use of online lessons during the pandemic emphasising the use of different platforms for passing information to their students and parents.

Career counselors shared their challenge of how to ensure inclusive career guidance process by responding to the needs of vulnerable groups of pupils who have difficulties in accessing the career guidance, namely pupils with special needs and people from rural areas. In order to respond to new policies and requirements, career counselors tried their best to ensure quality and inclusive career guidance services for their pupils. With the sudden move to an online career guidance, the issues of quality and access come to the forefront. The interviewed experts reported about flexibility towards the use of diverse forms of accessing participants. Some experts reported about the issues attached to a lack of technologies, and a limited access to a stable internet connection. The responses highlighted three aspects of the current digital divide: 1) availability of infrastructure and software to provide online services; 2 ) one's ability to create and to share digital content; 3) digital literacy to use those skills. Interviews with the career guidance experts highlighted that those issues were discussed for a long time but there are still many difficulties for quality online communication to take place (Hohleld et al., 2008). Career experts have emphasized the need for the new competencies that are necessary for survival and success in the situation of uncertainty and unknowing, in 
order to provide efficient help for the students to be successful and competitive in a job market. They needed to reinforce career management skills, such as career adaptability and resilience.

With regard to the problems and difficulties that they have encountered during the pandemic, career councillors responded in the following way: "A lot of information has been provided to the students, but this was not clear how much of it did they made good use of" (Anna, 52). "The students have encountered difficulties with the internet connection. Some students have adopted an attitude: "don't touch me." This is quite difficult to reach the students who are not willing to communicate, for example, who are ignoring mails" (Biruta, 50). Another response was related to the restrictions caused by the Covid-19 situation: "In the online format, the students perceive information differently; the availability of students has decreased and this made it difficult to get a feedback from them" (Cecilia, 28). Another comment was related to problems of a low response rate, interest and a fatigue among the students (Fjodor, 40). Career counsellors found themselves in the unknown situation. Each of them has been trying to do their best during the pandemic, but there were doubts whether they are doing the right thing. As one of the career counsellors has commented: "No one has taught us how to live, work and support others during the pandemic." Among the gains of the pandemic, they have mentioned such issues as mastering the use of new digital tools: "We and students have mastered new digital skills and how to use online resources" (Biruta, 50). Accessibility of the audience via online tools was another issue discussed by the career counsellors: "Students have a huge amount of information and lots of choices, limitless time for the remote learning and filling in online test that can be carried out in a slow speed; students had an opportunity to plan their time much better" (Elsa, 46). "There is more time to develop new materials and a programme for career counsellors how to build better cooperation with the teachers" (Fjodor, 40).

With regard to a sustainable career counselling process, career counsellors have placed more emphasis on students by taking care of them and their future plans: "What is invested in children, is invested in the sustainable future. Those students who have been participating in the project activities for four years know a lot about themselves and educational opportunities. The world is changing. In the next 20 years, $60 \%$ of the professions will disappear. Many people will have to re-qualify at different stages of their lives" (Anna, 52). Another response was related to a sustainability of career counselling programs: "A career education programme will help to continue a career counselling process in school after the project ends since career counselling programs depend on finding from the local government" (Biruta, 50). Another respondent related sustainability to "listening to the choices of students and helping them at different stages of their life: by following their progress, learning about the dynamics in student's interests and needs as they mature" (Elsa, 46).

\section{Conclusions}

The world has witnessed a global disruption that brought along changes in all spheres of the job market. The pandemic brought changes in the organization of work that reinforced career management skills, such as career adaptability and resilience. COVID-19 will increase youth unemployment and the exclusion of labor market seekers. Therefore, a greater support is necessary to prepare youth in dealing with uncertainty 
and unknowing. The pandemic has influenced short and long-term individual career opportunities and trajectories of individuals.

Cedefop et al. (2020) report potential of career guidance in a post-pandemic recovery process in terms of investment in education, labor market efficiency and social inclusion. Creative career guidance in a 'New Normal' requires helping individuals to rewrite their narrative identity, to establish their life purpose and to explore ways of action (Savickas et al., 2012). The purpose of career guidance is to ensure that students make wiser and more thoughtful decisions about their careers and connect their present with their imagined futures. Consulting via online resources can make career support more flexible, personalized, student-centered and more meaningful. Online learning allows practitioners to carry career guidance in a new format as more suitable for contemporary young persons.

By the use of online carrier support services, career counselors can develop client's psychological resources, such as resilience and competencies, to make a New Normal more bearable. The role of a career counselor is to guide people in understanding their situation. The career system is considered to be one of the important systems shaping one's identity and behavior. The new career system encompasses greater uncertainty and change and causes more pressure on the individual.

Focus group and individual group interviews with the career guidance experts indicate that they were trying their best to adjust to a New Normal and arrange a meaningful communication with the students in addressing their fears, concerns, and inspiring them for action. The pandemic highlighted several issues related to the organization of remote guidance: availability of infrastructure and software to provide online services; the ability to create and share digital content, and digital literacy to use those skills. The pandemic brought along issues of social inclusion and the need to develop experts' digital literacy. While some career counselors easily adjusted to a new situation, others needed more time to learn new skills and acquire new digital literacies.

The authors have proposed a conceptual model of sustainable career guidance that is based on current research proposals. These proposals suggest the need to view career advancement from the system perspective and through complex dynamic framework as influenced by a number of contextual factors and their intermingling. The model takes into account an individual's future orientation, their current resources and a unique motivational potential. The conceptual model offers a guideline and a mental framework for the career counselor to assist a young person to navigate in the sustainable future.

\section{References}

Airila, A., Hakanen, J. J., Schaufeli, W. B., Luukkonen, R., Punakallio, A., \& Lusa, S. (2014). Are job and personal resources associated with work ability 10 years later? The mediating role of work engagement. Work Stress, 28, 87-105.

Akkermans, J., Richardson, J., \& Kraimerc, M. L. (2020). The Covid-19 crisis as a career shock: Implications for careers and vocational behavior. Journal of Vocational Behavior, 119, 103434. doi: 10.1016/j.jvb.2020.103434

Bloch, D. (2003). The living career: Complexity, chaos, connections and career. In D. Bloch (Ed.), Global realities: Celebrating our differences, honoring our connections (pp. 219-227). https://files.eric.ed.gov/fulltext/ED480520.pdf 
Cedefop, European Commission, ETF, ICCDPP, ILO, OECD, UNESCO. (2020). Career guidance policy and practice in the pandemic: Results of a joint international survey. June to August 2020. Luxembourg: Publications Office of the European Union. http://data.europa.eu/doi/10.2801/318103

Cho, E. (2020). Examining boundaries to understand the impact of COVID-19 on vocational behaviors. Journal of Vocational Behavior, 119. https://doi.org/10.1016/ j.jvb.2020.103437

Chudzikowski, K. S., Gustafsson, K. S., \& Tams, S. (2020). Constructing alignment for sustainable careers: Insights from the career narratives of management consultants. Journal of Vocational Behavior, 117. doi: 10.1016/j.jvb.2019.05.009

De Vos, A., Beatrice I. J. M., Van der Heijdenb, \& Akkermanse, J. (2018). Sustainable careers: Towards a conceptual model. Journal of Vocational Behavior, 1-13.

Drodge, E. N. (2002). Career counseling at the confluence of complexity science and new career. M@n@gement, 1(5),49-62.

Duffy, R. D., Blustein, D. L., Diemer, M. A., \& Autin, K. L. (2016). The psychology of working theory. Journal of Counseling Psychology, 63(2), 127-148. https://doi.org/ 10.1037/cou0000140

Kira, M., \& Eijnatten, F. M. V. (2008). Socially sustainable work organizations: A chaordic systems approach. Systems Research and Behavioral Science, 25(6), 743-756.

Kira, M., van Eijnatten, F. M., \& Balkin, D. B. (2010). Crafting sustainable work: Development of personal resources. Journal of Organizational Change Management, 23, 616-632.

Haenggli, M., \& Hirschi, A. (2020). Career adaptability and career success in the context of a broader career resources framework. Journal of Vocational Behavior, 119, 103414. https://doi.org/10.1016/j.jvb.2020.103414

Heasly, B., Iliško, Dz., Salìte, I., \& Lindner, J. (2020). The value of process and pedagogy through the sustainability prism. Discourse and Communication for Sustainable Education, 11(2), 1-4. https://doi.org/10.2478/dcse-2020-0014

Heslin, P. A., Keating, L. A., \& Ashford, S. J. (2020). How being in learning mode may enable a sustainable career across the lifespan. Journal of Vocational Behavior, 117. doi: 10.1016/j.jvb.2019.103324

Hirschi, A. (2012). The career resources model: an integrative framework for career counsellors. British Journal of Guidance \& Counselling, 40(4), 369-383.

Hite, L. M., \& McDonald, K. S. (2020). Careers after COVID-19: Challenges and changes. Human Resource Development International, 23(4), 427-437, doi: 10.1080/13678868.2020.1779576

Hobfoll, S. E. (1989). Conservation of resources: A new attempt at conceptualizing stress. American Psychologist, 44(3), 513-524. doi: 10.1037/0003-066X.44.3.513

Lawrence, B. S., Hall, D. T., \& Arthur, M. B. (2017). Sustainable careers then and now. In A. DeVos \& B. I. J. M. Van der Heijden (Eds.), Handbook of research on sustainable Careers (pp. 432-449). Cheltenham, UK: Edward Elgar.

Millar, C. C., Groth, O., \& Mahon, J. F. (2018). Management Innovation in a VUCA World: Challenges and recommendations. California Management Review, 61, 514. doi: 10.1177/00081256188051

Obolensky, N. (2014). Complex adaptive leadership: Embracing paradox and uncertainty ( $2^{\text {nd }}$ Ed.) New York: Routledge. 
Pryor, R. G. L. (2010). A framework for chaos theory career counseling. Australian Journal of Career Development, 19(2), 32-40.

Pittman, J., Severino, L., DeCarlo Tecce, M. J., \& Kiosoglous, C. (2021). An action research case study: Digital equity and educational inclusion during an emergent COVID-19 divide. Journal for Multicultural Education. In Press. https://doi.org/ 10.1108/JME-09-2020-0099

Salìte, I., Fjodorova, I., Iliško, Dz., Ivanova, O., \& Meihami, H. (2020). JTES for Sustainable Development: An action research environment for the development and sustainable future of the journal identity. Journal of Teacher Education for Sustainability, 22(1), 1-5. doi: 10.2478/jtes-2020-0001

Savickas, M. L., \& Porfeli, E. J. (2012). Career adapt-abilities scale: Construction, reliability, and measurement equivalence across 13 countries. Journal of Vocational Behavior, 80, 661-673. doi: 10.1016/j.jvb.2012.01.011

UNESCO. (2020). Career guidance policy and practice in the pandemic: Results of a joint international survey - June to August 2020. Luxembourg: Publications Office of the European Union. http://data.europa.eu/doi/10.2801/318103

Correspondence concerning this paper should be addressed to Sandra Šapale, Daugavpils University, Latvia. Email: sandra.sapale@inbox.lv 